\title{
Corrigendum: Control of Sleep by Dopaminergic Inputs to the Drosophila Mushroom Body
}

\author{
Divya Sitaraman ${ }^{1,2 \dagger}$, Yoshinori Aso², Gerald M. Rubin ${ }^{2}$ and Michael N. Nitabach ${ }^{1,2,3,4 *}$ \\ ${ }^{1}$ Department of Cellular and Molecular Physiology, Yale University School of Medicine, New Haven, CT, USA, ${ }^{2}$ Janelia \\ Research Campus, Howard Hughes Medical Institute, Ashburn, VA, USA, ${ }^{3}$ Department of Genetics, Yale University School \\ of Medicine, New Haven, CT, USA, ${ }^{4}$ Program in Cellular Neuroscience, Neurodegeneration and Repair, Yale University \\ School of Medicine, New Haven, CT, USA
}

Keywords: sleep, Drosophila melanogaster, mushroom body, dopamine, synaptic transmission

\section{OPEN ACCESS}

Edited and reviewed by: Patrick O. Kanold,

University of Maryland, USA

*Correspondence:

Michael N. Nitabach

michael.nitabach@yale.edu

${ }^{\dagger}$ Present Address:

Divya Sitaraman

Department of Psychological Sciences, University of San Diego,

San Diego, CA, USA

Received: 17 November 2015 Accepted: 11 December 2015 Published: 22 December 2015

Citation: Sitaraman D, Aso Y, Rubin GM and Nitabach MN (2015) Corrigendum: Control of Sleep by Dopaminergic Inputs to the Drosophila Mushroom Body. Front. Neural Circuits 9:84 doi: 10.3389/fncir.2015.00084

\section{A corrigendum on}

Control of Sleep by Dopaminergic Inputs to the Drosophila Mushroom Body by Sitaraman, D., Aso, Y., Rubin, G. M., and Nitabach, M. N. (2015). Front. Neural Circuits 9:73. doi: 10.3389/fncir.2015.00073

The citation for the first use of P2X2 as an exogenous chemogenetic neural activator (Lima and Miesenbock, 2005) was inadvertently omitted from the manuscript on page 2, at the end of the first sentence of the Section entitled "Stimulation of PAM Neurons by ATP/P2X and Simultaneous GCamp6m Imaging of MBONs."

\section{REFERENCES}

Lima, S. Q., and Miesenbock, G. (2005). Remote control of behavior through genetically targeted photostimulation of neurons. Cell 121, 141-152. doi: 10.1016/j.cell.2005.02.004

Conflict of Interest Statement: The authors declare that the research was conducted in the absence of any commercial or financial relationships that could be construed as a potential conflict of interest.

Copyright (C) 2015 Sitaraman, Aso, Rubin and Nitabach. This is an open-access article distributed under the terms of the Creative Commons Attribution License (CC BY). The use, distribution or reproduction in other forums is permitted, provided the original author(s) or licensor are credited and that the original publication in this journal is cited, in accordance with accepted academic practice. No use, distribution or reproduction is permitted which does not comply with these terms. 